Kumawula, Vol. 3, No.2, Agustus 2020, Hal 129 - 139

DOI: https://doi.org/10.24198/kumawula.v3i2.24745

ISSN 2620-844X (online)

Tersedia online di http://jurnal.unpad.ac.id/kumawula/index

\title{
EDUKASI MITIGASI BENCANA DI DESA CINTAMULYA KECAMATAN JATINANGO, KABUPATEN SUMEDANG, PROVINSI JAWA BARAT
}

\author{
Ivan Darmawan ${ }^{1 *}$, Khairunnisa Della ${ }^{2}$, Putri Avelia ${ }^{3,}$ Muhammad Dhiyaul Haq $^{4}$ \\ ${ }^{1,2,4}$ Fakultas Ilmu Sosial dan Ilmu Politik Universitas Padjadjaran \\ ${ }^{3}$ Fakultas Pertanian Universitas Padjadjaran \\ *ivan.idevice@gmail.com
}

\begin{abstract}
ABSTRAK
Bencana alam dalam bentuk apapun merupakan hal yang sangat tidak diinginkan oleh siapapun. Namun, kejadian ini terus ada dan terjadi. Berbagai usaha yang dilakukan manusia seringkali masih kurang maksimal sehingga bencana masih sering tidak terelakkan. Manusia yang percaya pada Tuhan berusaha memahami segala kehendak-Nya, meski itu berarti penderitaan. Banyak masalah hadir bersamaan dengan datangnya bencana alam, seperti kehilangan dan kerusakan harta benda bahkan nyawa. Meski begitu, hal ini bukanlah perkara yang akan dengan mudah dipahami dan diterima oleh mereka yang terdampak. Harta yang telah dikumpulkan dan ditabung bertahun-tahun lamanya dapat lenyap dalam sekejap. Begitu juga sanak keluarga yang sangat dicintai dapat meninggalkan kita seketika. Maka dari itu, pentingnya mitigasi bencana sangat perlu disadari dan dimengerti oleh masyarakat, terlebih masyarakat di daerah rawan bencana, seperti halnyaDesa Cintamulya, Kecamatan Jatinangor, Kabupaten Sumedang, Jawa Barat.
\end{abstract}

Kata Kunci: Bencana Alam, Mitigasi Bencana, Edukasi

\begin{abstract}
Any kind of natural disaster is undesirable for anyone. Unfortunately, the incidents persist. Efforts that have been done have not been optimal that the disasters are often inevitable. Humans who believe in God attempts to comprehend all of God's will, though it would mean suffering. Many issues arise out of disasters, such as the loss and destruction of property and even lives. As such, this issue is not one that is easy to be understood and accepted for those who are affected. Wealth that has been collected for years can be erased in an instant. Loved ones can be lost in an instant as well. Thus, disaster mitigation needs to be realized and understood by the society, especially residents of areas vulnerable to disasters such as Cintamulya village, Jatinangor sub-district, Sumedang regency, West Java.
\end{abstract}

Keywords: Natural Disasters, Disaster Mitigation, Education

\section{PENDAHULUAN}

Undang-Undang Republik Indonesia nomor 24 tahun 2007 tentang Penanggulangan Bencana menjelaskan bahwa bencana merupakan peristiwa yang menggangu dan mengancam kehidupan dan penghidupan masyarakat yang dapat disebabkan karena faktor manusia, faktor 
alam, maupun faktor non-alam, dan menimbulkan kerusakan lingkungan, kerugian harta benda, dampak psikologis dan korban jiwa manusia. Adapun menurut lembaha kesehatan dunia World Health Organization (WHO), bencana dapat dikatakan sebagai setiap kejadian yang menyebabkan gangguan ekologis, kerusakan, hilangnya nyawa manusia, atau memburuknya derajat kesehatan atau pelayanan kesehatan pada skala tertentu yang memerlukan respon atau bantuan dari luar masyarakat terdampak atau wilayah yang terkena. Menanggapi definisi tentang bencana di atas, bahwa definisi bencana merujuk kepada karakteristik gangguan terhadap kehidupan normal, efek terhadap tatanan struktur sosial, dampak terhadap manusia, dan kebutuhan masyarakat.

Indonesia merupakan negara besar dengan bermacam-macam wilayah dan memiliki banyak penduduk, hal ini menyebabkannya memiliki berbagai potensi bencana yang sewaktuwaktu dapat terjadi. Maka dari itu dibutuhkan manajemen bencana secara komprehensif yang disebut siklus bencana. Siklus bencana adalah langkah-langkah pengelolaan bencana yang di dalamnya terdapat 4 komponen, yaitu mitigasi, kesiapsiagaan, respon dan pemulihan (Coppola, 2007). Mitigasi merupakan serangkaian upaya pencegahan dengan tujuan untuk menghindari dan meminimalisir kemungkinan terjadinya bencana serta konsekuensi yang akan ditimbulkan oleh bencana tersebut. Adapun kesiapsiagaan dapat dikatakan sebagai rangkaian kegiatan yang dilaksanakan untuk mengantisipasi kemungkinan dampak yang ditimbulkan bencana dengan melakukan pengorganisasian dalam rangka meningkatkan survival chance dan meminimalkan kerugian yang didapat dengan langkah yang berdaya guna dan tepat guna. Respon adalah rentetan rangkaian tindakan yang diambil dan dilakukan dengan sesegera mungkin saat terjadinya bencana untuk mengurangi dan/atau menghilangkan dampak bencana dengan tujuan mencegah penderitaan lebih lanjut, kerugian finansial serta dampak buruk yang paling mungkin terjadi. Terakhir, pemulihan diartikan sebagai kegiatan untuk mengembalikan kembali kehidupan korban ke keadaan normal setelah terkena dampak dari bencana.

Notoatmojo (dalam Sekarningrum dkk, 2020) Mengemukakan edukasi merupakan upaya untuk memberikan pengetahuan dan mempengaruhi orang lain baik individu, kelompok maupun masyarakat secara terencana sehingga mereka melakukan apa yang diharapkan oleh pendidik. Singkatnya, edukasi merupakan proses belajar menjadi tahu dan paham dari yang mulanya tidak mengetahui. Oleh karena itu, edukasi terkait mitigasi atau pencegahan bencana 
penting diberikan kepada masyarakat sebagai upaya untuk mengurangi kemungkinan terjadinya bencana serta risiko yang ditimbulkannya.

Kecamatan Jatinangor memiliki potensi bencana longsor, banjir, gempa bumi dan kebakaran dikarenakan letak geografis serta faktor sosiologisnya. Oleh karena itu, edukasi mitigasi bencana terkait beberapa bencana tersebut perlu diberikan kepada masyarakat, terutama masyarakat Desa Cintamulya Kecamatan Jatinangor. Hal ini sebagai upaya untuk mempersiapkan masyarakat atas bencana yang dapat datang sewaktu-waktu.

\section{Bencana Banjir}

Banjir merupakan fenomena alam yang seringkali terjadi di suatu kawasan, terutama yang banyak dialiri oleh aliran sungai (Simanjuntak, 2014). Banjir dapat juga terjadi karena debit atau volume air yang mengalir pada suatu sungai atau saluran drainase melebihi atau diatas kapasitas pengalirannya. Berdasarkan data dari Badan Nasional Penanggulangan Bencana (BNPB), dalam sepuluh tahun terakhir frekuensi terjadinya bencana banjir di Indonesia meningkat drastis serta luasan area dan dampak kerugian yang ditimbulkannya juga semakin besar.

Banjir yang terjadi di Indonesia dapat dikategorikan terjadi karena dua faktor, yaitu faktor manusia dan faktor alam. Faktor yang berasal dari manusia adalah perilaku masyarakat yang melakukan penggundulan hutan secara berkepanjangan sehingga berkurangnya daerah resapan air. Selain itu, tingkat pendidikan masyarakat Indonesia yang dapat dikatakan masih rendah juga menjadi salah satu faktor yang menyebabkan banjir terjadi. Menurut laporan United Nations Development Programme (UNDP) pada tahun 2014, bahwa rata-rata lama sekolah penduduk Indonesia hanya 7,5 tahun. Angka ini jauh di bawah sejumlah negara ASEAN lain seperti Singapura yang mencapai 10,2 tahun, Malaysia dengan 9,5 tahun, Filipina 8,9 tahun, dan bahkan Brunei Darussalam 8,7 tahun. Hal ini masih menjadi pr kita bersama sebagai warga negara Indonesia bersama pemerintah, meski tidak ada jaminan dengan tingginya tingkat pendidikan akan menurunkan angka bencana banjir. Adapun Faktor alam sendiri terbagi kepada beberapa hal, yang pertama adalah, Indonesia merupakan negara dengan curah hujan tinggi. Terdapat lebih dari 5000 sungai besar dan kecil di Indonesia yang kurang lebih 30 persen diantaranya melewati kawasan padat penduduk dan berpotensi akan terjadinya banjir pada saat musim hujan. (Pusat Penanggulangan Krisis Departemen Kesehatan RI, 2008). Selanjutnya adalah cuaca ekstrim, berdasarkan data dari Badan Meteorologi, Klimatologi dan Geofisika (BMKG) Republik Indonesia, bahwasanya 
meningkatnya kejadian bencana hidrometeorologi di beberapa wilayah Indonesia seperti banjir dan longsor dipicu dan dipengaruhi oleh kondisi atmosfer yang sangat labil di wilayah Indonesia.

\section{Gambar 1. Peta Indeks Ancaman Bencana Banjir}

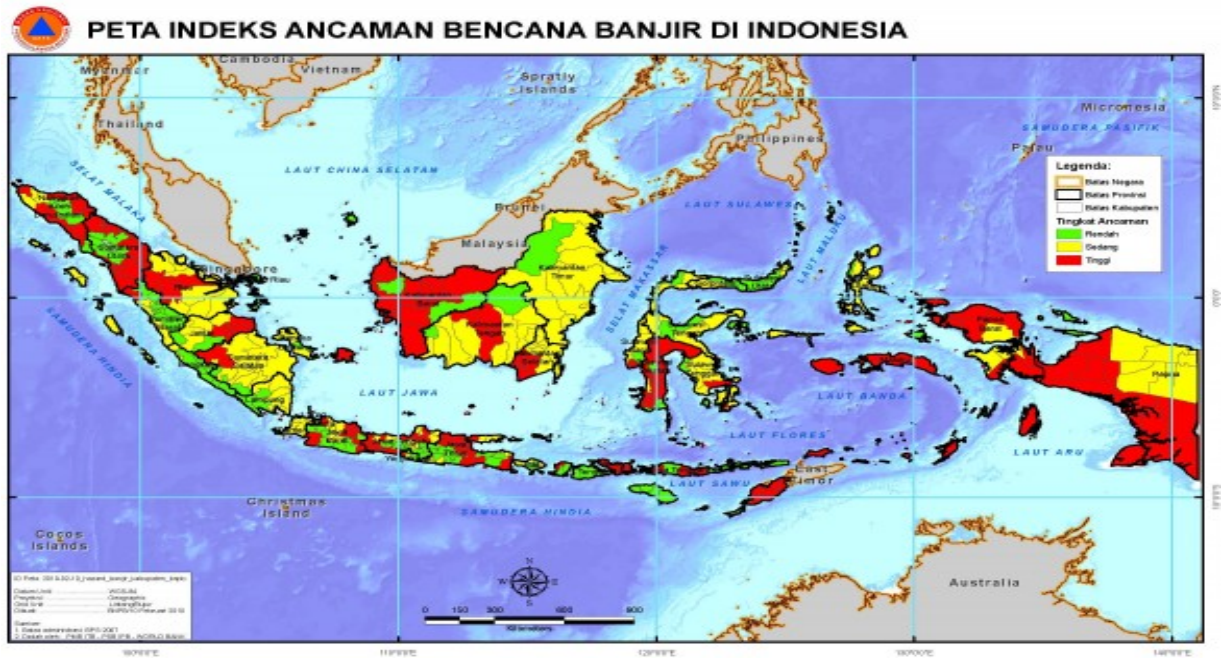

Di Indonesia, khususnya propinsi Jawa Barat, banjir merupakan bencana yang paling sering terjadi, terutama pada saat musim hujan. Banyak petani di pantura yang hanya bisa pasrah menyaksikan lahan pertanian dan perikanannya hancur diterjang banjir. Banjir tidak hanya menggenangi kawasan pemukiman di perkotaan tetapi juga sampai ke daerah perdesaan. Banjir juga sering terjadi di sekitar Daerah Aliran Sungai (DAS) Citarum terutama di bagian hulu. Salah satu kawasan di hulu sungai Citarum yang sering mengalami banjir adalah kampung Cieunteung. Kampung ini merupakan kampung yang merasakan dampak paling parah atas bencana banjir yang terjadi setiap tahunnya. Tak hanya itu, ratusan penduduk juga harus meninggalkan tempat tinggalnya untuk mengungsi ke tempat pengungsian karena rumah mereka tergenang banjir dan tidak bisa ditinggali. Bencana banjir yang terjadi telah mengganggu berbagai kegiatan penduduk baik untuk keperluan bekerja, pendidikan, maupun lainnya. Walaupun Desa Cintamulya tidak dilewati oleh Daerah Aliran Sungai Citarum, namun Desa Cintamulya yang terletak pada Kecamatan Jatinangor, Sumedang, Jawa Barat ini letaknya sangat dekat dengan DAS Citarum Harum, maka masyarakat Desa Cintamulya perlu mengetahui tentang pentingnya mitigasi bencana, salah satunya adalah bencana banjir itu sendiri yang sangat berpotensi akibat kurangnya pengetahuan masyarakat Cintamulya mengenai pengelolaan sampah, yang dapat 
mengakibatkan berpotensinya banjir di Desa Cintamulya sehingga diperlukannya mitigasi bencana pada masyarakat Desa Cintamulya.

\section{Bencana Gempa Bumi}

Gempa bumi adalah getaran bumi. Gempa bumi dapat terjadi oleh peristiwa letusan gunung api, tanah longsor, ledakan bom, benturan meteorit, dan banyak lagi penyebab lainnya; namun secara umumnya gempa bumi diakibatkan oleh pergeseran lempeng di kerak ataupun perut bumi di sepanjang bidang patahan (Abott, 2004). Pergeseran tersebut dapat terjadi karena setiap bebatuan menerima dan menyimpan tekanan tektonis yang dikirimkan oleh interaksi lempeng-lempeng litosfer, sedikit demi sedikit terakumulasi sedemikian rupa hingga gaya stress tersebut menjadi sedemikian besar dan mampu menggeser batuan di sepanjang bidang patahan. Pergeseran tersebut terjadi secara mendadak, menghantarkan gelombang kejutnya ke segala arah, yang kemudian dikenal sebagai gempa bumi (Husein, 2016).

Indonesia merupakan negara yang sangat rentan terhadap bencana gempa bumi. Hal ini disebabkan oleh dua faktor yang saling berkait berikut. (1) Pada saat ini posisi geologis Indonesia berada pada pertemuan 3 lempeng litosferik besar, yaitu Lempeng Eurasia, Lempeng Pasifik, dan Lempeng Indo-Australia; dimana gaya interaksi antar-lempeng tersebut senantiasa menekan dan menggeser berbagai patahan yang tersebar di seluruh bagian Indonesia, baik di daratan maupun di dasar lautan, yang telah ada semenjak lama. (2) Pada masa lampau selama puluhan juta tahun, Indonesia dibangun atas gabungan berbagai lempeng benua mikro dan busur gunung api, yang digerakkan oleh proses tektonik yang kompleks hingga berada di tempatnya saat ini; proses tumbukan puluhan lempeng tersebut menyebabkan terbentuknya berbagai jenis patahan yang tersebar di berbagai tempat, senantiasa menerima dan menimbun gaya tektonik dari interaksi lempeng-lempeng litosfer saat ini (Husein, 2016).

\section{Gambar 2. Peta Sesar Lembang}




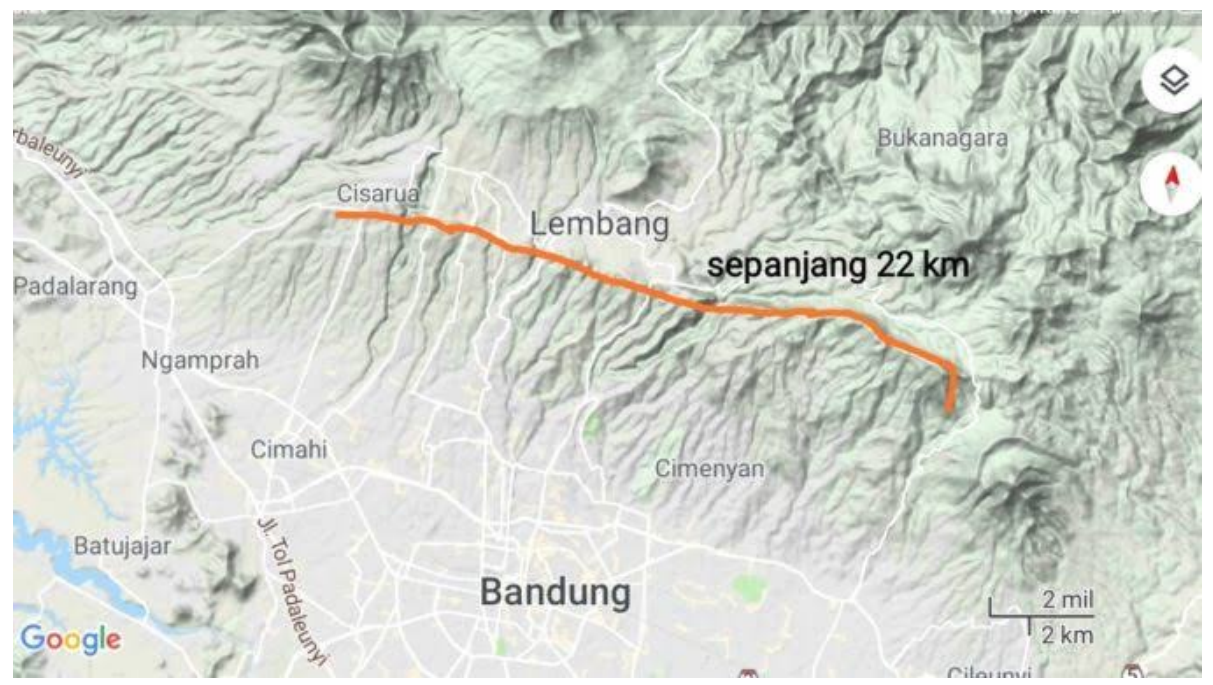

Desa Cintamulya berpotensi gempa bumi, dikarenakan Jawa Barat terletak bertepatan dengan Sesar Lembang. Sesar Lembang yang letaknya ternyata tidak lebih dari $30 \mathrm{~km}$ dari Kota Bandung, ternyata merupakan salah satu daerah yang termasuk rawan gempa. Berdasarkan hasil citra indraja menunjukan bahwa daerah lembang dilalui oleh sesar normal yang melintang sepanjang $22 \mathrm{~km}$. Dimana jalur sesar lembang ini merupakan tempat yang paling potensial untuk terjadinya gerakan bebatuan, hal ini disebabkan karena jalur sesar merupakan salah satu tempat atau media penyaluran gelombang gempa. Sehingga apabila terjadi gempa bumi yang berdekatan dengan daerah tersebut maka daerah yang akan mengalami getaran terbesar adalah lokasi-lokasi yang berada di sepanjang zona sesar. Maka dari itu, karena Desa Cintamulya dan Kecamatan Jatinangor berposisi sangat dekat dengan Kota Bandung turut berpotensi akan bencana gempa bumi tersebut.

\section{Bencana Kebakaran Pemukiman}

Kebakaran sejatinya masuk ke dalam kelompok salah satu bencana. Kebakaran merupakan bencana yang berdasarkan penyebab kejadiannya dapat digolongkan kepada dua hal, yakni digolongkan sebagai bencana alam (natural disaster) maupun bencana non-alam yang disebabkan karena kelalaian manusia (man-made disaster). Kebakaran sebagai golongan bencana alam dikarenakan faktor penyebabnya berasal dari alam. Faktor alamiah yang dapat menyebabkan kebakaran diantaranya adalah petir, gempa bumi, letusan gunung api, kekeringan dan lain-lain. Adapun kebakaran sebagai bencana non alam merupakan kebakaran yang diakibatkan kelalaian manusia. Faktor-faktor kelalaian manusia yang dapat menyebabkan kebakaran adalah berasal dari kebocoran tabung gas, puntung rokok yang 
dibuang sembarangan, hubungan arus pendek listrik, rendahnya sistem pengamanan konstruksi bangunan terhadap kebakaran, hingga sabotase, dan lain sebagainya.

Kebakaran merupakan suatu bencana yang memiliki potensi untuk selalu mengancam kehidupan manusia, karena kehadirannya tidak pernah dapat diduga kapan dan dimana terjadinya dan siapa saja yang akan menjadi korban. Oleh karena itu, sudah sepatutnya semua pihak harus melakukan upaya pencegahan untuk mengantisipasi kebakaran baik dalam segi sebelum terjadi ataupun ketika terjadi untuk mencegah meluasnya kebakaran sedini mungkin. Sebagian besar kejadian kebakaran terjadi di permukiman warga yang juga diakibatkan oleh faktor manusia, antara lain karena kecerobohan, kelalaian, ataupun ketidakpedulian.

Kemampuan masyarakat dalam mencegah dan menanggulangi kebakaran merupakan salah satu hal yang dapat dikembangkan dengan adanya edukasi kepada masyarakat. Urgensi edukasi ini menjadi hal yang penting untuk dapat menekan terjadinya bencana kebakaran. Tidak hanya itu, kemampuan masyarakat dalam hal mitigasi bencana diharapkan dapat menjadi salah satu senjata dan upaya dalam proses pencegahan dan penanggulangan bencana kebakaran secara mandiri. Desa Cintamulya itu sendiri memiliki potensi terjadinya bencana kebakaran, dikarenakan kondisi dan struktur pemukiman yang cukup padat dimana jarak antara satu rumah dengan rumah yang lain sangat berdekatan, sehingga apabila terjadi kebakaran api akan dengan sangat mudah menjalar dan akan semakin sulit untuk diatasi.

\section{METODE}

Metode yang digunakan pada program ini adalah metode pendekatan partisipatif. Metode pendekatan partisipatif adalah salah satu jenis penelitian kualitatif yang melihat fenomena sosial secara lebih luas dan mendalam sesuai dengan apa yang terjadi dan berkembang atas situasi sosial tertentu. Metode ini lebih mendasarkan dirinya pada tingkat kebaruan informasi atau kadar aktualitas informasi yang diperoleh secara langsung dari lapangan. Kebaruan informasi itu dapat berupa upaya lingkungan untuk memahami secara lebih luas dan mendalam atas gejala-gejala sosial yang terjadi di masyarakat. Untuk dapat menentukan apa yang akan menjadi fokus pada program ini, maka peneliti melakukan grand observation dan grand tour question atau yang disebut penjelajahan umum ke lapangan. Selanjutnya, dalam observasi partisipatif peneliti terlibat secara langsung dengan kegiatan sehari-hari subjek yang diamati atau digunakan sebagai sumber data penelitian. Dimana peneliti ikut melakukan apa yang dikerjakan subjek penelitian dan ikut merasakan suka dan duka yang dirasakannya sambil tetap melakukan pengamatan. Dengan menggunakan metode observasi partisipan, 
peneliti berharap data yang diperoleh akan lebih lengkap, tajam dan mendalam sampai kepada tingkat makna dari setiap perilaku yang nampak maupun yang tidak nampak. Melalui metode dan pendekatan ini, Tim KKN Desa Cintamulya melakukan observasi lapangan, mapping tempat-tempat yang berpotensi banjir, pengamatan secara langsung, serta outputnya adalah untuk melakukan penyuluhan atau workshop kepada sasaran yang menurut kami tepat untuk dilakukannya penyuluhan ini, yaitu adalah perwakilan dari bapak-bapak dan karang taruna Desa Cintamulya.

\section{HASIL DAN PEMBAHASAN}

Pada Desa Cintamulya, belum pernah dilakukannya edukasi mengenai mitigasi bencana. Maka dari itu, output yang dilakukan oleh Tim KKN Desa Cintamulya adalah melakukan workshop mengenai edukasi mitigasi bencana kepada perwakilan bapak-bapak Desa Cintamulya, Sebelum melakukan workshop, kami telah melakukan pemetaan pada Desa Cintamulya, yaitu pemetaan tempat-tempat rawan banjir, gempa bumi, dan titik kumpul evakuasi. Kegiatan yang kita lakukan adalah melakukan pemetaan (mapping) lokasi potensi banjir yang ada di desa cintamulya, yaitu desa yang terdekat dengan desa cintamulya yang memiliki aliran sungai yang searah seperti desa cisempur, desa cipasir, desa cikijing. Aliran sungai desa cisempur dan aliran sungai desa cipasir awal nya searah dengan aliran sungai yang ada di desa cintamulya tetapi semenjak adanya pabrik PT Kahatex aliran sungai tersebut diputuskan yang awal nya aliran sungai tersebut bersih dan melewati sawah menjadi terputus karena didirikannya pabrik kahatex tersebut yang menyebabkan aliran sungai tersebut menjadi masuk ke dalam pabrik dan di olah oleh pabrik kahatex yang sekarang di konsumsi oleh masyarakat di desa cintamulya. Kenapa desa cintamulya berpotensi banjir dikarenakan tanggul saluran sungai yang berada di desa cintamulya ditutup dan menjadi tempat pembuangan sampah. Selain itu kami juga melakukan observasi mengenai kebiasaankebiasaan masyarakat desa Cintamulya yang menjadi salah satu faktor terjadinya bencanabencana tersebut seperti kurangnya edukasi atas mitigasi bencana, pengelolaan sampah, dan hal lain terkait mitigasi bencana. Berikut hasil dan dokumentasi :

\section{Gambar 3. Peta Potensi Bencana Gempa Bumi dan Banjir}




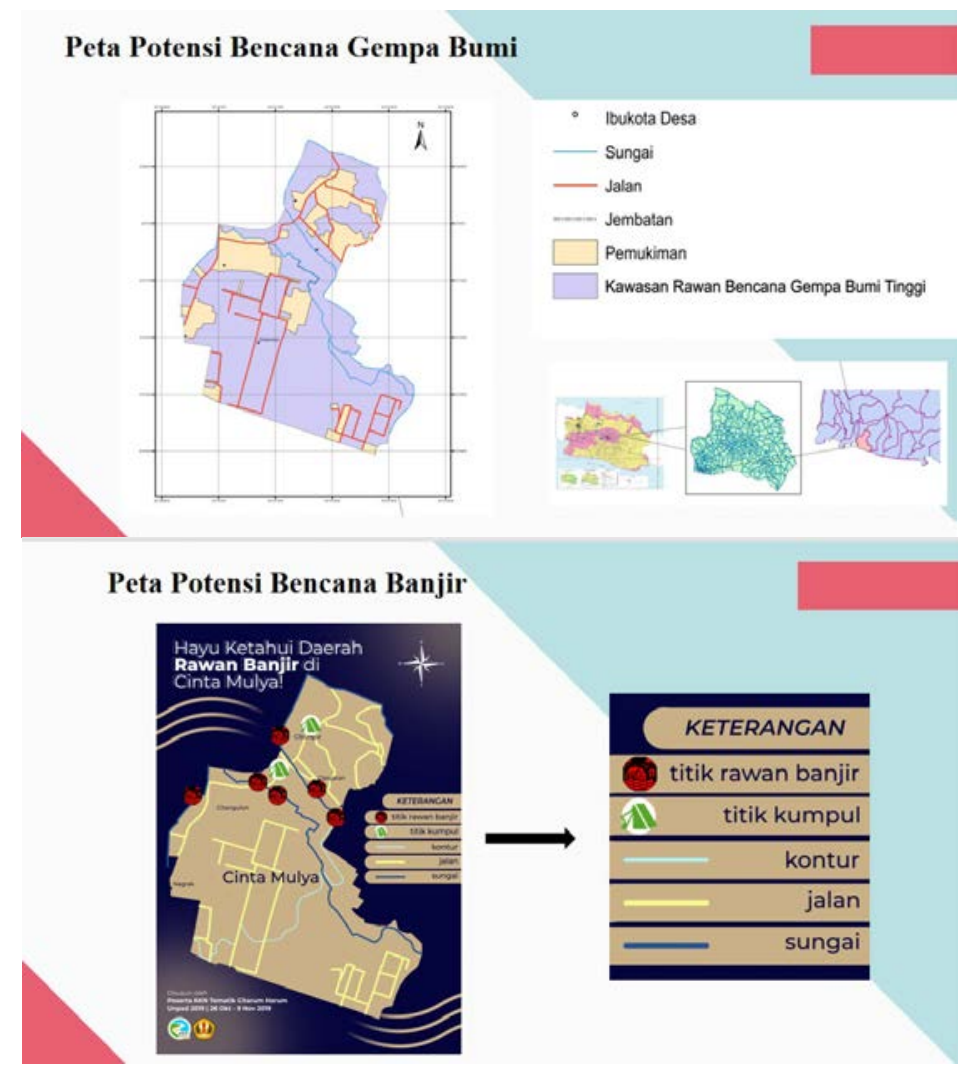

Gambar 4. Dokumentasi Hasil Survei

Dokumentasi Hasil Survei
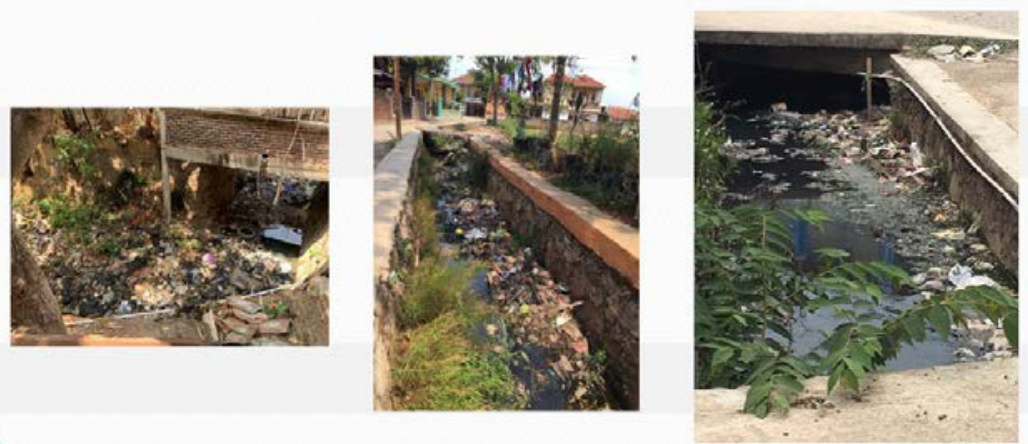

Pada workshop itu sendiri, Tim KKN Cintamulya telah memberikan tiga materi mengenai mitigasi bencana, yaitu materi bencana banjir, gempa bumi, dan kebakaran. Pada workshop, diberikannya edukasi mengenai factor-faktor pemicu bencana, resiko bencana, serta mitigasi bencana itu sendiri.

\section{Gambar 5. Workshop Mitigasi Bencana}




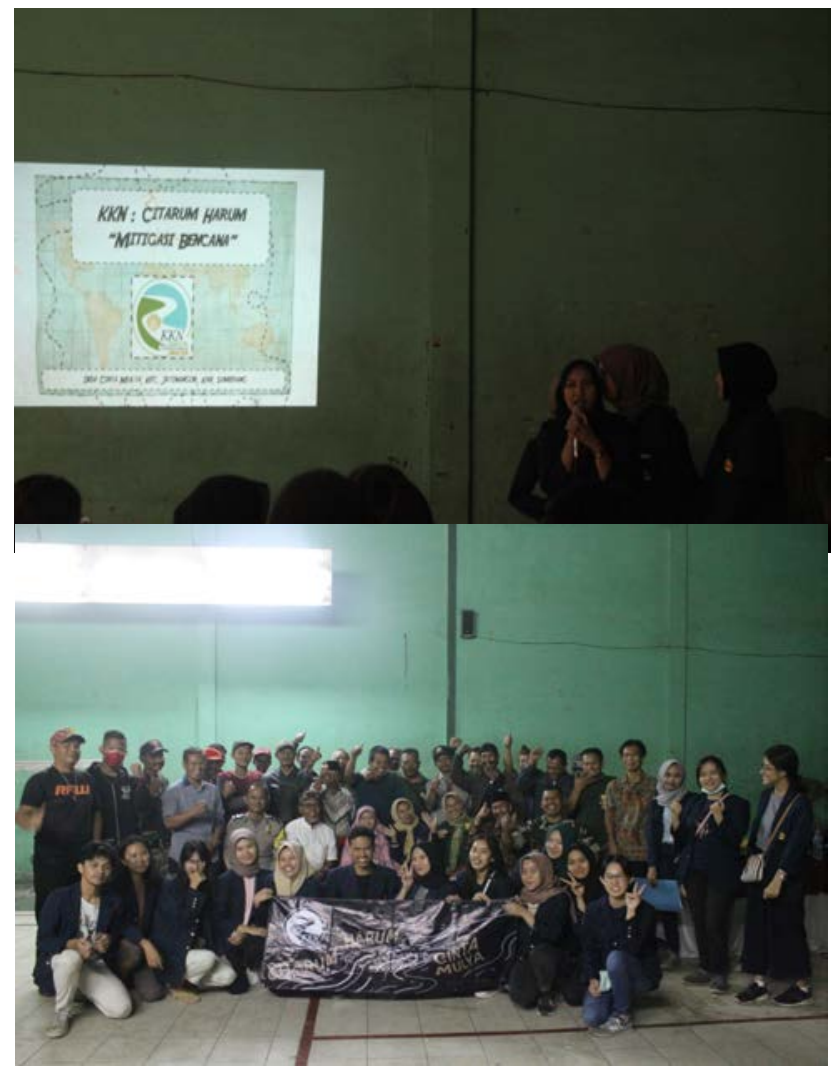

Pada bencana banjir itu sendiri, masyarakat desa Cintamulya masih sangat kurang edukasi mengenai pengelolaan sampah, dimana hal ini akan sangat berpotensi bencana banjir. Pada workshop ini, dilakukannya pemberian materi mengenai pengelolaan sampah, namun permasalahan utama menurut masyarakat adalah dikarenakannya belum adanya Tempat Pembuangan Sampah (TPS) di desa Cintamulya ataupun Tempat Pembuangan Akhir (TPA) yang berada di sekitar Desa Cintamulya, sehingga masyarakat desa masih membuang sampah sembarangan, membakar sampah, dan masih belum peduli terhadap sanitasi lingkungan. Pada akhirnya, Tim KKN Desa Cintamulya juga melakukan pembuatan PKM-M yang akan ditunjukkan kepada pemerintah guna membantu permasalahan ini yang terdapat pada Desa Cintamulya.

\section{KESIMPULAN}

Kondisi Desa Cintamulya sendiri sebenarnya sudah berkembang, akan tetapi masih banyak masalah yang harus dilakukan oleh warga yang ada di Desa Cintamulya sendiri. Permasalahan yang pertama yang ada di Desa Cintamulya sendiri tentang mitigasi bencana banjir adalah belum adanya edukasi mengenai pengelolaan sampah, serta TPS dan TPA di Desa Cintamulya itu sendiri. Dan permasalahan yang yang kedua tentang mitigasi bencana 
kebakaran sendiri belum ada nya tempat titik kumpul yang terletak di Desa Cintamulya sendiri dikarenakan kepadatan penduduk yang mengakibatkan belum adanya lahan kosong yang dijadikan sebagai tempat evakuasi atau titik kumpul masyarakat Desa Cintamulya. Kesimpulannya, dikarenakan belum pernah adanya edukasi mengenai mitigasi bencana, maka masyarakat Desa Cintamulya masih sangat kurang pengetahuan akan hal ini, dengan adanya program ini, diharapkan masyarakat Desa Cintamulya kemudian bisa lebih paham mengenai segala faktor, resiko, dan hal-hal yang menyebabkan potensi bencana, serta edukasi tentang mitigasi bencana itu sendiri.

\section{DAFTAR PUSTAKA}

Abott, P.L. (2004). Natural Disasters: 4th ed. McGraw Hill Higher Education: Boston.

Coppola, D. P. (2007). Introduction to International Disaster Management. Oxford: Elsevier. Husein, Salahuddin. (2016). Bencana Gempa Bumi. Universitas Gadjah Mada: Yogyakarta. Immadudina, Annisa. (2011). Zonasi risiko bencana banjir akibat sea level rise, Surabaya: Institut Teknologi Sepuluh Nopember.

Informasi Kinerja Pengelolaan Lingkungan Hidup Daerah (IKPLHD) 2016 Provinsi Jawa Timur.

Muslim, Aziz. (2003). Konsep Dasar dan Pendekatan Pengembangan Masyarakat, Yogyakarta: Jurnal PMI. Vol. I No. I.

Nurjanah, R. S., Kuswanda D., Siswanto B., P. dan Adikoesoemo. (2012). Manajemen Bencana. Bandung: Alfabeta.

Nurwulandari, F. S. (2016). Kajian mitigasi bencana kebakaran di permukiman padat. Unniversitas Pasundan: Bandung.

Pusat Penanggulangan Krisis Departemen Kesehatan RI. (2008). Penanggulangan Krisis Kesehatan Akibat Bencana di Indonesia. Jakarta: Kementrian Kesehatan.

Sekarningrum, B., Yogi S., dan Desi Y. (2020). Sosialisasi dan Edukasi Kangpisman (Kurangi, Pisahkan dan Manfaatkan Sampah). Kumawula: Jurnal Pengabdian Masyarakat. 3(1). 73-86. Doi: https://doi.org/10.24198/kumawula.v3i1

Silitonga, P. H., \& Indonesia. (1973). Peta geologi lembar Bandung, Djawa: Geologic map of the Bandung quadrangle, Java / by P.H. Silitonga. Bandung: Direktorat Geologi. 
Suryanto., Bambang H., Rusdin. (2020). Edukasi Fintech Bagi Pelaku Usaha Mikro, Kecil, dan Menengah. Kumawula: Jurnal Pengabdian Masyarakat. 3(1). 18-28. Doi: https://doi.org/10.24198/kumawula.v3i1

Undang-Undang Republik Indonesia Nomor 24 Tahun 2007 Tentang Penanggulangan Bencana

Van Bemmelen, R.W. (1949). The Geology of Indonesia. Vol I-A, General Geology, The Haque, Martinus Nijhoff.

World Health Organization. (2009). ICN framework of disaster nursing competencies. Geneva: World Health Organization 